\title{
Association of a Pyruvate Kinase M2 (PKM2) Polymorphism with Back Fat Thickness in Berkshire Pigs
}

\author{
Eun-Seok Cho, Hyeon-Jeong Jeon, Si-Woo Lee, Jong-Woon Park, Sebastian Raveendar, Gul-Won Jang, \\ Tae-Hun Kim and Kyung-Tai Lee* \\ Animal Genomics and Bioinformatics Division, National Institute of Animal Science, RDA, Suwon 441-706, Korea
}

\begin{abstract}
Pyruvate kinase M2 (PKM2) is a key regulatory enzyme in the glycolytic pathway. It is one of four pyruvate kinase isoenzymes that widely differ in their occurrence according to tissue type. PKM2 is expressed in differentiated tissues, such as fat tissues, lung, as well as normal proliferating cells, embryonic cells, and tumor cells. The objective of this study was to investigate the association of single nucleotide polymorphisms (SNPs) in the PKM2 gene with meat quality traits in Berkshire pigs. We detected a SNP $(g .34341 A>G)$ in the 3'UTR region of the PKM2 gene in 670 Berkshire pigs through DNA sequencing. Three genotypes, AA, AG, and GG, were found for this SNP, but based on an association analysis with meat quality traits, genotype AA was significantly associated with thicker back fat than genotype GG $(\mathrm{p}=0.027)$. Therefore, the $g .34341 A>G$ polymorphism in the 3'UTR region of the porcine $P K M 2$ gene could be applied in pig breeding programs to improve back fat thickness.
\end{abstract}

(Key words : Meat quality, Pyruvate Kinase M2, Pig, Single nucleotide polymorphism)

\section{INTRODUCTION}

Meat quality is attributed to various factors such as genetics, muscle characteristics, as well as production and environmental conditions. Understanding the metabolic pathways involved in fat formation is particularly important for quality meat production from farm animals. In pork, back fat thickness (BF) and intramuscular fat content (IMF) are major factors that affect the sensory meat quality and highly considered as selection criteria in commercial markets (Gerbens et al., 2001; Cho et al., 2011). Genetic markers have been applied to improve the fatness and meat quality of pigs (Markljung et al. 2008; Li et al. 2010; Fan et al. 2010). In earlier studies, QTLs related to fatness and meat quality traits, such as intramuscular fat content (de Koning et al., 1999; Gerbens et al., 1999, 2000; Ovilo et al., 2000; Grindflek et al., 2001; Uleberg et al., 2005) and backfat thickness (Malek et al., 2001; Ovilo et al., 2002; Szyda et al., 2003; Soma et al., 2011) were identified on chromosome 6 (SSC6).

Pyruvate kinase has four different isoforms: M1, M2, L, and R. M1 and M2 isoforms are in the muscle, heart, and brain, whereas $\mathrm{L}$ and $\mathrm{R}$ forms are found in the liver and erythrocytes (Takegawa, Shinohara, and Miwa, 1984). M1 and M2 isoforms are encoded from the PKM (Pyruvate Kinase Muscle) gene (Noguchi, Inoue, and Tanaka, 1986) located in q12-q23 on porcine chromosome 7 (Davoli et al., 2002; Fontanesi et al., 2004), a region associated with highly reported to contain QTLs related to meat quality, fat deposition, and growth traits (Bidanel et al., 2001; Gilbert et al., 2007; Malek et al., 2001; Nezer et al., 2002; Ovilo et al., 2002; Reiner et al., 2002; Rohrer and Keele, 1998; Yue et al., 2003). PKM2 is a particularly promising positional candidate gene that plays a crucial role in porcine meat quality (Duan et al, 2009). Therefore, determining the PKM2 gene polymorphisms associated with meat quality could be useful for marker-assisted selection in pig breeding programs. In this investigation, PKM2 gene polymorphisms were tested for their association with meat quality traits in a Berkshire pig population. This study contributes to a better understanding of molecular factors associated with meat quality in livestock.

* Corresponding author: Kyung-Tai Lee, Ph.D. Animal Genomics and Bioinformatics Division, National Institute of Animal Science, RDA, 564 Omockchun-Dong, Gwonseon-Gu, Suwon 441-706, Korea. Tel: +82-31-290-1591, Fax: +82-31-2901602, E-mail: leekt@korea.kr 
Cho et al.; Single Nucleotide Polymorphism in Porcine PKM2 Gene Affecting Back Fat Thickness

\section{MATERIALS AND METHODS}

The study protocol and standard operating procedures were reviewed and approved by the Institutional Animal Care and Use Committee of the National Institute of Animal Science (Suwon, Republic of Korea)

\section{Animals and trait measurements}

A total of 670 Berkshire pigs (307 castrated males and 363 females) were used in the association study. The pigs were fed with the same commercial diet at the same pig farm and slaughtered at an average body weight of $110 \mathrm{~kg}$. Slaughter was conducted according to standard procedures under the supervision of a Korean grading service for animal products. Following slaughter, the hot carcass weight was recorded and the back fat thickness was measured between the $10^{\text {th }}$ and $11^{\text {th }}$ ribs. Meat quality traits were then evaluated from the longissimus dorsi muscle. Nine items were measured: meat characteristics, meat $\mathrm{pH}$ (measured 24 hours after slaughter), water-holding capacity (WHC), drip loss, cooking loss, meat color, muscle shear force, moisture, IMF, and crude protein. The water-holding capacity of the longissimus dorsi was immediately sampled after slaughter using the filter-paper method described by Grau and Hamm (1952, 1956). In addition, drip loss during vacuum storage was determined 1 day postmortem by weighing samples before and after storage. Cooking loss was measured as the difference between sample weights before and after incubation at $75^{\circ} \mathrm{C}$ for $10 \mathrm{~min}$. Meat color was measured using three coordinates from the Hunter L, a, b system, where $\mathbf{L}$ is a general indication of lightness, $\mathbf{a}$ represents the degree of green-redness, and $\mathbf{b}$ represents the degree of blueyellowness. Shear force was determined using a WarnerBratzler shear force meter (G-R Electrical, USA). The moisture, fat content, and crude protein were analyzed according to the American Organization of Analytical Chemists methodology (Arlington, 1980). The overall means and standard deviations of the 14 traits are shown in Table 1.

\section{SNP detection and genotyping}

Genomic DNA was extracted from EDTA-treated blood samples using a Wizard Genomic DNA Purification Kit (Promega, Madison, WI, USA) according to the manufacturer's instructions. The primers used to amplify the porcine PKM2
Table 1. Mean, standard deviation (SD), and ranges for the traits measured in 670 pigs

\begin{tabular}{lrccc}
\hline Traits & Mean & SD & Min & Max \\
\hline \hline CWT (kg) & 85.98 & 5.51 & 71 & 105 \\
pH24 & 5.77 & 0.19 & 5.37 & 6.72 \\
WHC (\%) & 58.40 & 3.38 & 50.13 & 67.82 \\
Drip loss (\%) & 4.43 & 1.91 & 12.30 & 14.38 \\
Cooking loss (\%) & 26.51 & 4.16 & 12.30 & 39.02 \\
MC_L & 48.49 & 2.75 & 38.00 & 57.68 \\
MC_a & 6.26 & 1.04 & 3.40 & 9.62 \\
MC_b & 3.14 & 1.21 & 0.33 & 6.85 \\
BF (mm) & 25.10 & 5.20 & 12 & 41 \\
SF (kg/0.5 inch2) & 3.08 & 0.80 & 1.45 & 6.14 \\
Moisture (\%) & 75.17 & 1.12 & 69.98 & 77.57 \\
Fat (\%) & 2.67 & 1.18 & 0.42 & 10.15 \\
Protein (\%) & 23.76 & 0.88 & 20.95 & 26.24 \\
Collagen (\%) & 0.89 & 0.13 & 0.53 & 1.39 \\
\hline
\end{tabular}

SD, standard deviation; CWT, carcass weight; WHC, water holding capacity; MC_L, CIE_lightness; MC_a, CIE_redness; MC_b, CIE_yellowness; BF, back fat; SF, shear force.

gene were designed from published genomic DNA sequences (Ensembl: ENSSSCG00000001930). The porcine PKM2 gene was amplified from 96 genomic DNA samples from Berkshire pigs and sequenced to detect polymorphic sites. PCR was performed in a $20 \mu \mathrm{L}$ volume containing 10 pmol of each primer, $0.25 \mathrm{mM}$ of each dNTP, $2 \mu \mathrm{L}$ 10X PCR buffer, 1.25 U DNA polymerase (Genet Bio, Chungnam, Korea), and 100 ng genomic DNA. The thermal cycling conditions included an initial denaturation for $5 \mathrm{~min}$ at $94^{\circ} \mathrm{C}$ followed by 35 cycles of $30 \mathrm{~s}$ at $94^{\circ} \mathrm{C}, 30 \mathrm{~s}$ at $62^{\circ} \mathrm{C}$, and 1 min at $72^{\circ} \mathrm{C}$, with a final $10 \mathrm{~min}$ extension at $72^{\circ} \mathrm{C}$ in a DNA Engine $\operatorname{Tetrad}^{\circledR} 2$ Thermal Cycler (Bio-Rad, Hercules, CA, USA). To detect differences in the nucleotide sequences, direct sequencing of the PCR products was performed using a Big Dye Terminator Cycle Sequencing Ready Reaction Kit V3.0 (Life Technologies Corp., Carlsbad, CA, USA) and an ABI PRISM ${ }^{\circledR} 3730$ Genetic Analyzer (Life Technologies Corp.). The sequences were compared to find SNPs using the SeqMan program (DNASTAR Inc., Madison, WI, USA). PKM2 genotypes, determined by direct sequencing of the PCR product from 670 Berkshire pigs, were used for the association study. The primers used for direct sequencing were 5'-TTGGGTGGGGTAGTTCAGAG-3' and 5'-AGACAGTCAGCAACGGCTTT-3'. 


\section{Statistical analysis}

Association analyses were performed using SAS 9.13 (SAS Institute Inc., Cary, NC, USA). The following formula was used in generalized linear model (GLM) analysis: $y_{i j k l m n}=\mu+$ $G_{i}+S_{j}+P_{k}+e_{i j k l}$, where $y_{i j k l m n}$ is the observed value, $\mu$ is the general mean, $\mathrm{Gi}$ is the fixed effect of genotype $\mathrm{i}, \mathrm{Sj}$ is the fixed effect of sex $\mathrm{j}, \mathrm{Bk}$ is the fixed effect of breed $\mathrm{k}$, $\mathrm{Pk}$ is the fixed effect of the period of slaughter $\mathrm{k}$, and $e_{i j k l}$ is the random error. The results were presented as the least squares means for each group and standard errors (SEs) of the least squares means. Genotype, sex, and period of slaughter were included as fixed effects in the statistical model. Differences were considered significant at $p<0.05$. All data were expressed as the mean $\pm \mathrm{SE}$.

\section{RESULTS AND DISCUSSION}

\section{Genomic organization of porcine PKM2 gene}

The genomic structure of the porcine PKM2 gene, a putative exon region, was predicted from the GenBank and Ensembl sequence (Acc. No. XM_003356683, Ensembl: ENSSSCG00000001930) and contained fourteen exons and thirteen introns spanning approximately $46 \mathrm{~kb}$ of genomic DNA. The translation initiation codon was located in exon 1 (Table 2). Furthermore, all exon/intron boundary sequences followed the GT-AG rule for splice-donor and acceptor sites reported by Jacob and Gallinaro (1989).

\section{SNP identification and genotype frequencies}

The porcine PKM2 wasamplified by PCR and directly sequenced to identify genetic variations in pig samples from the Berkshire population. In our preliminary sequence analysis, one SNP was found at g.34341 $A>G$ in the 3' UTR region of the PKM2 (Fig. 1). To estimate the genotypic and allelic frequencies of this SNP in the porcine PKM2, a total of 670 Berkshire pigs were genotyped and the allele and genotype frequencies of $g .34341 A>G$ in the Berkshire pigs determined (Table 3). The genotype distribution of g.34341 $A>G$ in the Berkshire pigs conformed to Hardy-Weinberg equilibrium in this study. In the Berkshire population, the estimated frequencies of genotypes $\mathrm{AA}, \mathrm{AG}$, and $\mathrm{GG}$ were $0.17,0.50$, and 0.58 , respectively. Hence, the $G$ allele $(0.58)$ was slightly more common than the A allele (0.42).

\section{Association study}

The statistical analysis results from 670 animals in a commercial Berkshire population are presented in Table 4. The g.34341 $A>G$ SNP of the PKM2 gene was significantly associated with the $\mathrm{BF}$ trait and animals with the GG genotype had lower BF values than animals with AA or AG

Table 2. Exon-intron organization of the porcine PKM2 gene

\begin{tabular}{ccccr}
\hline Exon & Position & Exon size $(\mathrm{bp})$ & Intron & Intron size (bp) \\
\hline \hline 1 & $1 \sim 129$ & 129 & 1 & 799 \\
2 & $929 \sim 1,008$ & 80 & 2 & 397 \\
3 & $1,406 \sim 1,469$ & 64 & 3 & 151 \\
4 & $1,621 \sim 1,705$ & 85 & 4 & 19,288 \\
5 & $20,994 \sim 21,175$ & 182 & 5 & 512 \\
6 & $21,688 \sim 21,779$ & 92 & 6 & 2,856 \\
7 & $24,636 \sim 24,767$ & 132 & 7 & 454 \\
8 & $25,222 \sim 25,408$ & 187 & 8 & 714 \\
9 & $26,123 \sim 26,393$ & 271 & 9 & 1,626 \\
10 & $28,020 \sim 28,170$ & 151 & 10 & 240 \\
11 & $28,411 \sim 28,563$ & 153 & 11 & 3,335 \\
12 & $31,899 \sim 32,065$ & 167 & 12 & 1,803 \\
13 & $33,869 \sim 34,050$ & 182 & 13 & 581 \\
14 & $34,632 \sim 35,358$ & 727 & & \\
\hline
\end{tabular}

The gene structure was defined by evidence-based gene annotation method using a total of 140 expressed sequence tags and reference genome sequence (accession no. NC_010449) of the porcine PKM2 gene from NCBI database. 
Cho et al. ; Single Nucleotide Polymorphism in Porcine PKM2 Gene Affecting Back Fat Thickness

Table 3. Allele and genotype frequencies of PKM2 polymorphisms in Berkshire pigs

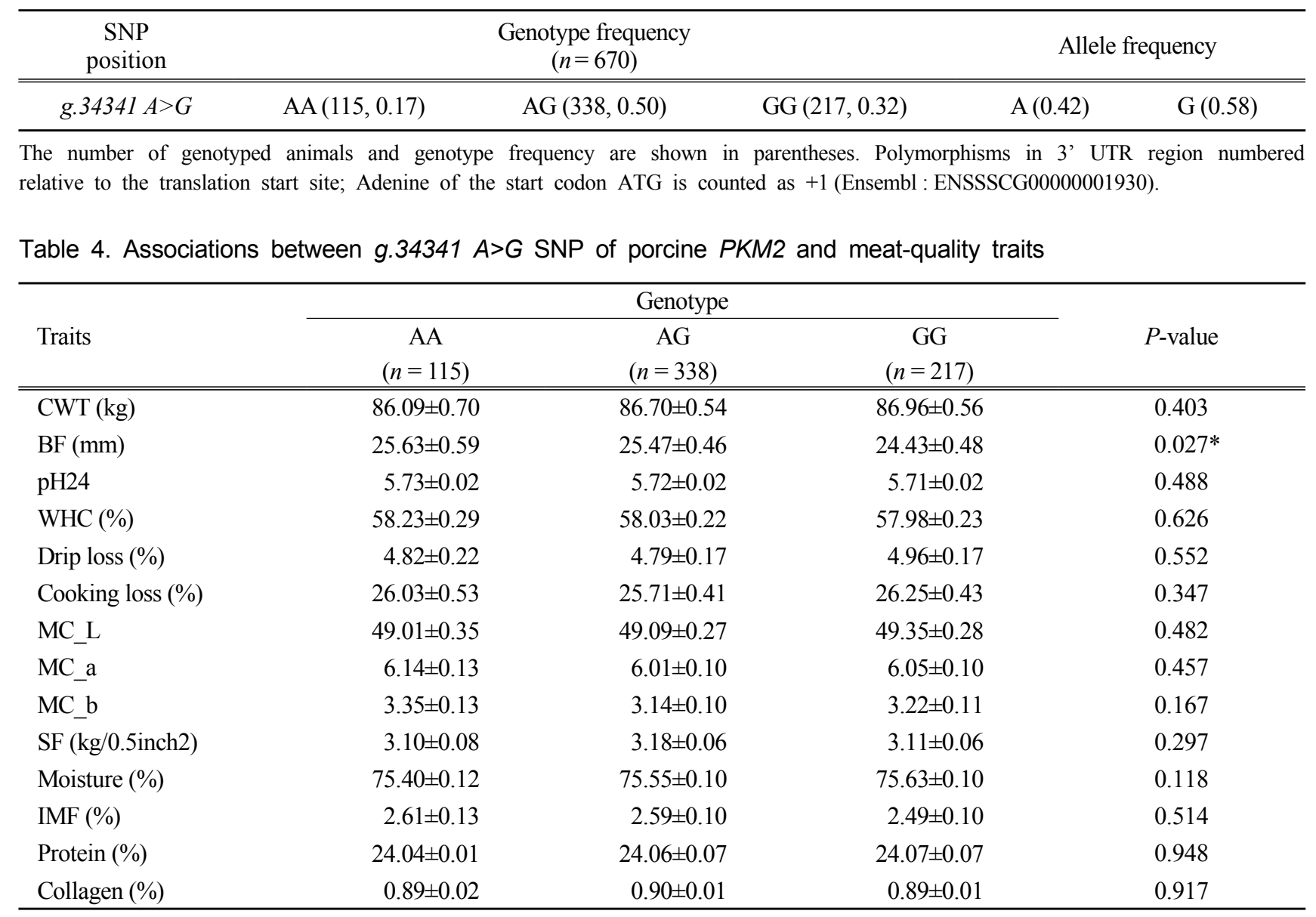

Abbreviations: CWT, carcass weight; BF, back fat thickness; WHC, water-holding capacity; MC_L, CIE_lightness; MC_a, CIE_redness; MC_b, CIE_yellowness; SF, shear force; IMF, intramuscular fat content;

$*, P<0.05$.

genotypes ( $\mathrm{P}=0.027)$. However, the $g .34341 A>G$ was not a source of variability for the other traits. The PKM2 gene encodes the muscle isoform of a rate-limiting enzyme that catalyses the conversion of phosphoenolpyruvate to pyruvate

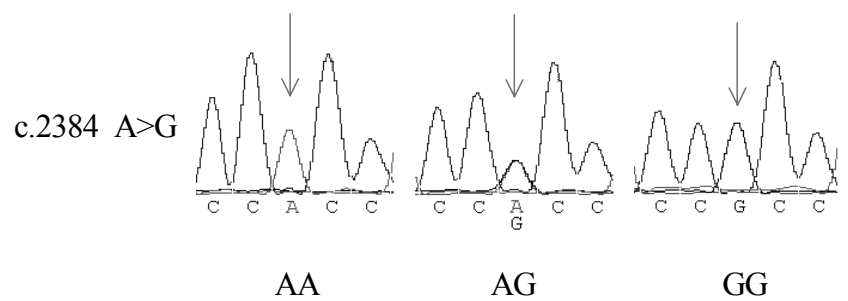

Fig. 1. Sequencing results and polymorphic sites found in the 3' UTR region of the porcine PKM2 gene in Berkshire pigs. Adenine of the start codon ATG is considered +1 (Ensembl: ENSSSCG00000001930). in the final step of glycolysis (Cairns et al, 2011) and has also been reported to have a role in muscle glyconeogenesis (Gleeson, 1996). In addition, this gene is on porcine chromosome 7, where several studies have indicated the presence of a QTL that affects meat quality traits. PKM2 is a strong candidate for meat quality in this region and has also been reported to impact back fat thickness as a powerful candidate gene (Fontanesi et al., 2008).

\section{CONCLUSION}

The purpose of this study was to find a molecular marker for the improved meat-quality using candidate gene analysis. The g.34341 $A>G$ SNP within the 3' UTR of the PKM2 gene was significantly associated with $\mathrm{BF}(p<0.05)$, an economically important trait in pigs. The potential advantage 
Cho et al.; Single Nucleotide Polymorphism in Porcine PKM2 Gene Affecting Back Fat Thickness

of marker-assisted selection would be reduced costs for sib testing after slaughter, a reduction in sophisticated meatquality measurements, as well as additional improvements in meat-quality by early information from genetic markers (Ovilo et al. 2006). However, although the results of this study provide evidence for the potential of SNP markerassisted selection of Berkshire pigs, the effects of SNP markers need to be compared to the meat-quality traits of pigs carrying different genotypes, as the effects of an allele may vary between pig populations. In addition, since the SNP is located in the 3' UTR, it is difficult to determine the direct effect of the PKM2 genotypes on meat-quality traits. Whether the association is due to the candidate gene requires further verification and association studies in other regions are also needed.

\section{ACKNOWLEDGMENTS}

This work was supported by 2-7-10 Agenda Research (PJ00670701) from the National Institute of Animal Science, a grant (PJ008068) from the Next-generation BioGreen 21 Program, Rural Development Administration, Republic of Korea, and the 2013 Postdoctoral Fellowship Program of the Rural Development Administration, Republic of Korea.

\section{REFERENCES}

Arlington, V. A. 1980. Official methods of analysis of the association of analytical chemists 14th edition. Washington: AOAC.

Bidanel, J.-P., Milan, D., Iannuccelli, N., Amigues, Y., Boscher, M.-Y., Bourgeois, F., Caritez, J.-C., Gruand, J., Roy, P. L. and Lagant, H. 2001. Detection of quantitative trait loci for growth and fatness in pigs. Genet. Sel. Evol. 33:289-310.

Cairns, R. A., Harris, I. S. and Mak, T. W. 2011. Regulation of cancer cell metabolism. Nat. Rev. Cancer, 11:85-95.

Cho, K., Kim, M., Jeon, G. and Chung, H. 2011. Association of genetic variants for FABP3 gene with back fat thickness and intramuscular fat content in pig. Mol. Biol. Rep. 38:2161-2166.

Davoli, R., Fontanesi, L., Zambonelli, P., Bigi, D., Gellin, J., Yerle, M., Milc, J., Braglia, S., Cenci, V. and Cagnazzo, M. 2002. Isolation of porcine expressed sequence tags for the construction of a first genomic transcript map of the skeletal muscle in pig. Anim. Genet. 33:3-18.

de Koning, D. J., Janss, L. L., Rattink, A. P., van Oers, P. A., de Vries, B. J., Groenen, M. A., van der Poel, J. J., de Groot, P.
N. and van Arendonk, J. A. 1999. Detection of quantitative trait loci for backfat thickness and intramuscular fat content in pigs (Sus scrofa). Genetics. 152:1679-1690.

Duan, Y. Y., Ma, J. W., Yuan, F., Huang, L. B., Yang, K. X., Xie, J. P., Wu, G. Z. and Huang, L. S. 2009. Genome-wide identification of quantitative trait loci for pork temperature, $\mathrm{pH}$ decline, and glycolytic potential in a large-scale White Duroc $\times$ Chinese Erhualian resource population. J. Anim. Sci. 87:9-16.

Fan, B., Lkhagvadorj, S., Cai, W., Young, J., Smith, R., Dekkers, J., Huff-Lonergan, E., Lonergan, S. and Rothschild, M. 2010. Identification of genetic markers associated with residual feed intake and meat quality traits in the pig. Meat Sci. 84:645650.

Fontanesi, L., Davoli, R., Nanni Costa, L., Beretti, F., Scotti, E., Tazzoli, M., Tassone, F., Colombo, M., Buttazzoni, L. and Russo, V. 2008. Investigation of candidate genes for glycolytic potential of porcine skeletal muscle: Association with meat quality and production traits in Italian Large White pigs. Meat Sci. 80:780-787.

Fontanesi, L., Davoli, R., Scotti, E. and Russo, V. 2004. Study of candidate genes for glycolytic potential of porcine skeletal muscle: identification and analysis of mutations, linkage and physical mapping and association with meat quality traits in pigs. Cytogenet. Genome Res. 102:145-151.

Gerbens, F., De Koning, D., Harders, F., Meuwissen, T., Janss, L., Groenen, M., Veerkamp, J., Van Arendonk, J. and Te Pas, M. 2000. The effect of adipocyte and heart fatty acid-binding protein genes on intramuscular fat and backfat content in Meishan crossbred pigs. J. Anim. Sci. 78:552-559.

Gerbens, F., Van Erp, A., Harders, F., Verburg, F., Meuwissen, T., Veerkamp, J. and Te Pas, M. 1999. Effect of genetic variants of the heart fatty acid-binding protein gene on intramuscular fat and performance traits in pigs. J. Anim. Sci. 77, 846-852.

Gerbens, F., Verburg, F., Van Moerkerk, H., Engel, B., Buist, W., Veerkamp, J. and Te Pas, M. 2001. Associations of heart and adipocyte fatty acid-binding protein gene expression with intramuscular fat content in pigs. J Anim. Sci. 79:347-354.

Gilbert, H., Le Roy, P., Milan, D. and Bidanel, J. -P. 2007. Linked and pleiotropic QTLs influencing carcass composition traits detected on porcine chromosome 7. Genet. Res. 89:6572.

Gleeson, T. T. 1996. Post-exercise lactate metabolism: a comparative review of sites, pathways, and regulation. Annu. Rev. Physiol. 58:565-581.

Grau, R. and Hamm, R. 1952. Eine einfache Methode zur Bestimmung der Wasserbindung in Fleisch. Fleischwirtschaft. 
4:295-297.

Grau, R. and Hamm, R. 1956. Die Bestimmung der Wasserbindung des Fleisches mittels der Pressmethode. Fleischwirtschaft. 8: 733-736.

Grindflek, E., Szyda, J., Liu, Z. and Lien, S. 2001. Detection of quantitative trait loci for meat quality in a commercial slaughter pig cross. Mamm. Genome. 12:299-300.

Jacob, M. and Gallinaro H. 1989. The 5' splice site: phylogetic evalution and variable geometry of association with U1RNA. Nucleic Acids Res. 17:2159-2180.

Li, H., Lund, M., Christensen, O., Gregersen, V., Henckel, P. and Bendixen, C. 2010. Quantitative trait loci analysis of swine meat quality traits. J Anim. Sci. 88:2904-2912.

Malek, M., Dekkers, J. C., Lee, H. K., Baas, T. J., Prusa, K., Huff-Lonergan, E. and Rothschild, M. F. 2001. A molecular genome scan analysis to identify chromosomal regions influencing economic traits in the pig. II. Meat and muscle composition. Mamm. Genome. 12:637-645.

Markljung, E., Braunschweig, M. H., Karlskov-Mortensen, P., Bruun, C. S., Sawera, M., Cho, I. -C., Hedebro-Velander, I., Josell, Å., Lundström, K. and von Seth, G. 2008. Genomewide identification of quantitative trait loci in a cross between Hampshire and Landrace II: meat quality traits. BMC genet. 9:22.

Nezer, C., Moreau, L., Wagenaar, D. and Georges, M. 2002. Results of a whole genome scan targeting QTL for growth and carcass traits in a Pietrain $\times$ Large White intercross. Genet. Sel. Evol. 34:371-388.

Noguchi, T., Inoue, H. and Tanaka, T. 1986. The M1-and M2-type isozymes of rat pyruvate kinase are produced from the same gene by alternative RNA splicing. J. Biol. Chem. 261:1380713812.

Ovilo, C., Clop, A., Noguera, J., Oliver, M., Barragan, C., Rodriguez, C., Silió, L., Toro, M., Coll, A. and Folch, J.
2002. Quantitative trait locus mapping for meat quality traits in an Iberian $\times$ Landrace F2 pig population. J. Anim. Sci. 80: 2801-2808.

Ovilo, C., Pérez-Enciso, M., Barragán, C., Clop, A., Rodríguez, C., Oliver, M. A., Toro, M. A. and Noguera, J. L. 2000. A QTL for intramuscular fat and backfat thickness is located on porcine chromosome 6. Mamm. Genome. 11:344-346.

Reiner, G., Heinricy, L., Müller, E., Geldermann, H. and Dzapo, V. 2002. Indications of associations of the porcine FOS protooncogene with skeletal muscle fibre traits. Anim. Genet. 33: 49-55.

Rohrer, G. and Keele, J. 1998. Identification of quantitative trait loci affecting carcass composition in swine: I. Fat deposition traits. J. Anim. Sci. 76:2247-2254.

Soma, Y., Uemoto, Y., Sato, S., Shibata, T., Kadowaki, H., Kobayashi, E. and Suzuki, K. 2011. Genome-wide mapping and identification of new quantitative trait loci affecting meat production, meat quality, and carcass traits within a Duroc purebred population. J. Anim. Sci. 89:601-608.

Szyda, J., Grindflek, E., Liu, Z. and Lien, S. 2003. Multivariate mixed inheritance models for QTL detection on porcine chromosome 6. Genet. Res. 81:65-73.

Takegawa, S., Shinohara, T. and Miwa, S. 1984. Hemin-induced conversion of pyruvate kinase isozymes in K562 cells. Blood. 64:754-757.

Uleberg, E., Widerøe, I., Grindflek, E., Szyda, J. and Lien, S. 2005. Fine mapping of a QTL for intramuscular fat on porcine chromosome 6 using combined linkage and linkage disequilibrium mapping. J. Anim. Breed. Genet. 122:1-6.

Yue, G., Stratil, A., Cepica, S., Schröffel, J., Schröffelova, D., Fontanesi, L., Cagnazzo, M., Moser, G., Bartenschlager, H. and Reiner, G. 2003. Linkage and QTL mapping for Sus scrofa chromosome 7. J. Anim. Breed. Genet. 120:56-65.

(Received Oct. 23, 2013; Revised Oct. 28, 2013; Accepted Oct. 29, 2013) 